\title{
Ethical and Social Justice Issues in Language and Literacy Research
}

\author{
ROSAMUND STOOKE \\ The University of Western Ontario \\ SUZANNE SMYTHE \\ Simon Fraser University
}

The 2011 Special Issue of Language \& Literacy was inspired by "exquisite conversations" (Lather, 2007) that took place during the 2010 Language and Literacy Researchers of Canada (LLRC) pre-CSSE conference held at Concordia University in Montreal. As in previous years, the preconference aimed to provide a forum for in-depth dialogue. Delegates participated in small group conversations to discuss each other's work as well as current research in the field. In their respective conversation groups, and leading off from ideas proposed in a keynote address by Dr. Mary Hamilton of Lancaster University's Literacy Research Centre, the 2010 delegates explored questions such as: What are the roles of texts and institutions, including research texts, in projects of "social ordering"? How is "the global instantiated in the local" as learners, educators and researchers negotiate in their everyday lives and work, education policies originating in supranational settings (Hamilton, 2009)?

Dr. Hamilton advocated an approach to the study of policy that "focuses on the everyday practices and realities of those participating in it" (Hamilton \& Hillier, 2007, p. 591). In her address, she described a study in which she and Yvonne Hillier (Hamilton \& Hillier, 2007) traced gaps and tensions between adult literacy policy, practice and research in the United Kingdom through an examination of the "accountability frameworks that so perplex and frustrate teachers in many educational contexts" (see Hamilton, this issue). Her contribution to the Special Issue draws readers' attention to a media scandal in the United Kingdom. The scandal precipitated the shutting down of a famous tabloid newspaper, the News of the World, and the resignations of several high-ranking public officials. To paraphrase one commentator, the newspaper that delighted in making people accountable has been held to account for its own actions. Hamilton's commentary takes a different tack to illuminate ways in which texts and literacy practices are at work in organizing official and unofficial accounts of the scandal which is still unfolding as this issue of Language \& Literacy "goes to press." She writes, "The issues of hidden, deleted and unread literacy artefacts are as prominent and powerful as the public revelation and creation of others."

Each article that appears in the Special Issue takes up Hamilton's advice to pay attention to practices that usually escape notice and to trace ways in which those practices participate in the unfolding of the seemingly mundane events that shape "life as usual."

Jan Pennycook's article employs critical discourse analysis to examine how beginning and experienced teachers employed in Ontario secondary schools engaged with the Ministry of Education's boy-friendly initiatives. Pennycook found that teachers cited a "failing boys" discourse that was not supported by a comparison of boys' and girls' scores on standardized literacy assessments. She argues that the "boys' literacy problem" discourse obscures the many other complex ways in which ethnicity, class and gender shape the distribution of literacy resources in children's classrooms and beyond. 
In two papers that describe their practices as teacher educators, Janette Hughes and Lorayne Robertson describe projects in which pre-service teachers engaged in critical literacy practices and implemented critical literacy strategies in practicum placements. Hughes and Robertson asked pre-service teachers to consider how critical language and literacy pedagogies can engage their students in conversations about social justice and the workings of media texts, and to provoke new ways of looking at and acting on issues of equity. They also modeled critical literacy in their own teaching, bringing the practices alive to these future teachers and thus available for exploration in their own teaching practice.

Several articles consider relations of power embedded in research, foregrounding the idea that issues of ethics and equity permeate all aspects of research relations with important consequences for knowledge production. Tara-Lynn Scheffel's paper is a reflexive examination of her interactions with study participants in a classroom-based ethnographic study of grade two students' literacy engagement. She notes, "Though I did not realize it at the time, the structure of my study was foundational to my ability to frame trustworthiness as social action. What I learned was that it was not only the importance of recognizing these methodological concerns that would promote integrity in my work, but the negotiation of the tensions along the way."

Saskia Stille similarly reflects upon the role of teacher and researcher identities in shaping research knowledge about children's literacies. She describes the competing values and interests teachers and researchers may bring to the collective work of improving literacy learning for children. Themes emerging from her grade five classroom ethnography suggest that acknowledging these different stances, and attending to the processes of research, as well as the processes of children's text production, will illuminate much more of what is promising and generative in literacy pedagogies than a usual concern for "products".

Marlene Asselin, Ray Doiron and Jon Shapiro capture ethical and equity issues embedded in the globalization of literacy research. They interrogate literacy research funded by alternative sources that is carried out in developing countries, noting that the global policy regimes guiding donor-funded research projects in these regions often reflect the policy priorities and literacy definitions of powerful groups outside the local research settings. Within these complex relations, the authors identify actions and values for Canadian literacy researchers working within the spirit and letter of the $2^{\text {nd }}$ Tri-Council Policy Statement of Research with Humans (NIHR \& HRCC, 2009) that include the adoption of broad views of literacy and participatory research methods, the promotion of people's right to define the meanings of literacy in their own lives, and the representation of these literacy meanings within trusting and respectful research relationships and publication regimes.

The perspectives gathered in this issue of Language \& Literacy help us to see that the work of creating more just, equitable and ethical relations in the teaching and researching of languages and literacies is tied to a willingness to engage with "big picture" policy discourses and their instantiation in the everyday life worlds of classrooms, staffrooms, research project teams and proposal writing. As Hamilton reminds readers, "Schooled literacies are specialized, just as the forensic literacies of the courtroom are, but what goes on in the each of these domains affects the others. We have to understand literacy in its many guises within this whole."

\section{References}

Canadian Institutes of Health Research, Natural Sciences and Engineering Research Council of Canada, and Social Sciences and Humanities Research Council of Canada. (2010). TriCouncil policy statement on research with humans. Retrieved from 
http://www.pre.ethics.gc.ca/pdf/eng/tcps2/TCPS_2_FINAL_Web.pdf

Hamilton, M. (2009). Putting words in their mouths: the alignment of identities with system goals through the use of Individual Learning Plans. British Educational Research Journal, 35(2), 221-242.

Hamilton, M., \& Hillier, Y. (2007). Deliberative policy analysis: Adult literacy assessment and the politics of change. Journal of Educational Policy, 22(5), 573-594.

Lather, P. (2007). Getting lost: Feminist efforts toward a double(d) science. Albany, NY: SUNY.

\section{Author Biography}

Rosamund Stooke is Assistant Professor at The University of Western Ontario. Her primary research focus is the educational work of parents and practitioners in community-based, informal literacy programs for families with young children, in particular the social organization of the work and its potential to support or constrain social inclusion.

Suzanne Smythe is a Lecturer in Literacy and Adult Education in the Faculty of Education at Simon Fraser University. Her core experiences as a literacy educator are in the realm of adult education, but she brings to her research insights into schooling experiences across the lifespan, paying close attention to the ways in which families' linguistic, cultural and material resources shape their relations with schools. 